\title{
Attritional rupture of the extensor pollicis longus tendon due to calcified extensor carpi radialis tendon group: a case report
}

\author{
Ekstansör karpi radialis tendon grubunda kalsifikasyona bağlı \\ ekstansör pollisis longus tendonu yıpranma kopması: Olgu sunumu
}

\author{
Kadir Ertem, MD., ${ }^{1}$ Zeynep Maraş Özdemir, MD., ${ }^{2}$ Gökay Görmeli, MD., ${ }^{1}$ Muhammed Köroğlu, MD. ${ }^{1}$ \\ 'Department of Orthopedics and Traumatology, Medical Faculty of İnönü University, Malatya, Turkey \\ ${ }^{2}$ Department of Radiology, Medical Faculty of İnönü University, Malatya, Turkey
}

\begin{abstract}
In this article, we report a case with spontaneous rupture of extensor pollicis longus tendon due to calcified extensor carpi radialis tendon group, which has not been published in the literature previously. Successful thumb extension was achieved in a 68-year-old male patient with the transfer of the extensor indicis proprius tendon at two months postoperatively. It appears that calcified extensor carpi radialis tendon group constitutes high risk for a possible attritional rupture of the extensor pollicis longus tendon.
\end{abstract}

Keywords: Calcification; tendon injuries; tenosynovitis.

The etiology of spontaneous rupture of the extensor pollicis longus tendon (SREPL) includes systemic or local steroid injections, wrist fracture, tenosynovitis, synovitis, rheumatoid arthritis, gouty tenosynovitis, and repetitive hand and wrist motions (such as milking cow, goalkeeping, or downhill skiing). ${ }^{[1-8]}$

This report presents an attritional SREPL related calcific extensor carpi radialis tendon group (ECRTG) in a farmer patient with no apparent predisposing factor, which has not been published in the literature previously. ${ }^{[9]}$

\section{CASE REPORT}

A 68-year-old male farmer patient was admitted to our clinic with pain in his right wrist and inability to extend his right thumb. Four years ago, he had a history of wrist pain that was alleviated after two weeks with cast immobilization and nonsteroidal anti-
$\ddot{O} Z$

$\mathrm{Bu}$ yazıda daha önce literatürde bildirilmemiş, kalsifiye ekstansör karpi radialis tendon grubuna bağlı gelişen, ekstansör pollisis longus tendonunun spontan kopması olgusu sunuldu. Altmış sekiz yaşında erkek hastada ekstansör indisis proprius tendon transferi yapılarak ameliyattan iki ay sonra yeterli başparmak ekstansiyonu elde edildi. Kalsifiye ekstansör karpi radialis tendon grubunun olası bir ekstansör pollisis longus tendonu yıpranma kopması bakımından yüksek risk oluşturduğu görülmektedir.

Anahtar sözcükler: Kalsifikasyon; tendon yaralanmaları; tenosinovitler.

inflammatory drug medication. He had no history of local or systemic steroid injection, rheumatoid arthritis (RA), or trauma. On physical examination, tenderness and swelling were detected on the second extensor compartment and thumb. Loss of thumb extension was identified at the interphalangeal joint. The clinical findings clearly indicated a rupture of the extensor pollicis longus (EPL). Rheumatoid factor was negative. Both C-reactive protein level $(0.05 \mathrm{mg} / \mathrm{dL})$ and erythrocyte sedimentation rate $(4 \mathrm{~mm} /$ hour $)$ were within the normal range $(<0.035 \mathrm{mg} / \mathrm{dL}$ and $<20 \mathrm{~mm}$ /hour, respectively). Posteroanterior and lateral radiographs revealed regular and linear soft tissue calcification adjacent to the dorsal aspect of the distal radius (Figure 1a, b). Magnetic resonance imaging (MRI) demonstrated calcification and ossification of the ECRTG and the ossification started from the distal $6.5 \mathrm{~cm}$ away from the musculotendinous junction and

- Received: March 23, 2015 Accepted: July 29, 2015

- Correspondence: Kadir Ertem, MD. İnönü Üniversitesi Tıp Fakültesi Ortopedi ve Travmatoloji Anabilim Dalı, 44315 Malatya, Turkey. Tel: +90 422 - 3410660 / 5110 e-mail: kadir.ertem@inonu.edu.tr 


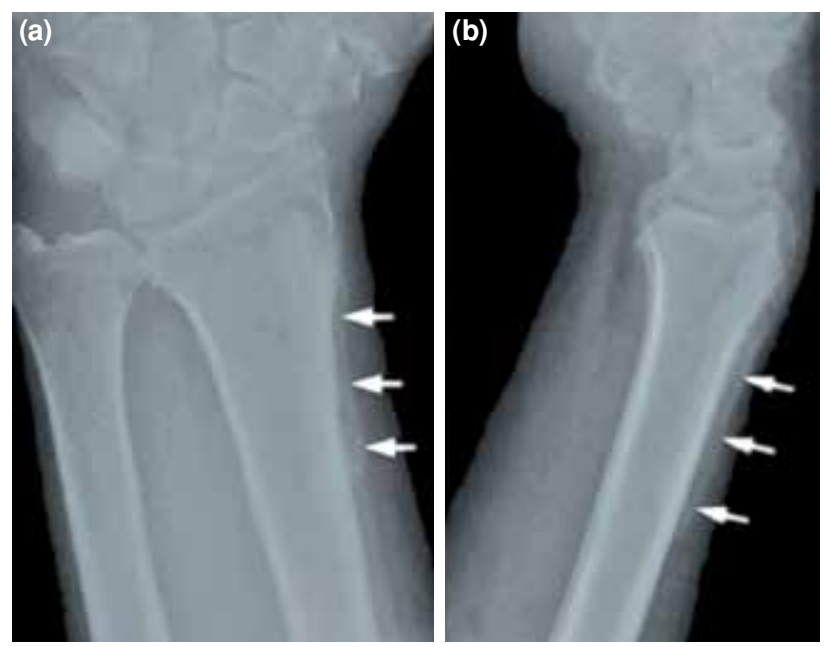

Figure 1. Posteroanterior (a) and lateral (b) radiographs show a linear soft tissue calcification adjacent to dorsal aspect of radius (arrows).

continued up to the 2-3 $3^{\text {th }}$ metacarpal basis (Figure 2a-c). During surgical exploration, the distal stump of the EPL was found at the level of Lister tubercle. The proximal stump could not be identified due to its retraction toward the forearm. There was calcification of ECRTG along the second extensor compartment and, ruptured EPL was crossing these calcific tendons. As the repaired tendon level was beyond the calcified tendon section, no surgical extraction of the calcified tendon tissue was accomplished. After the removal of atrophic and degenerative areas at the distal end of EPL, the extensor indicis proprius (EIP) tendon was transferred to the distal stump of the EPL by using Pulvertaft technique. The hand was immobilized in a short arm cast including thumb for six weeks. Then, the patient was encouraged for active mobilization and sent to physiotherapy unit for rehabilitation of the hand. After two months of follow-up, the patient was capable of active extension of his right thumb completely. An informed consent was obtained from the patient.

\section{DISCUSSION}

The etiology of calcific tendonitis of the hand and wrist is still unclear, but two hypotheses are postulated. The former is based on intratendinous necrosis from microtrauma as daily overuse is necessary
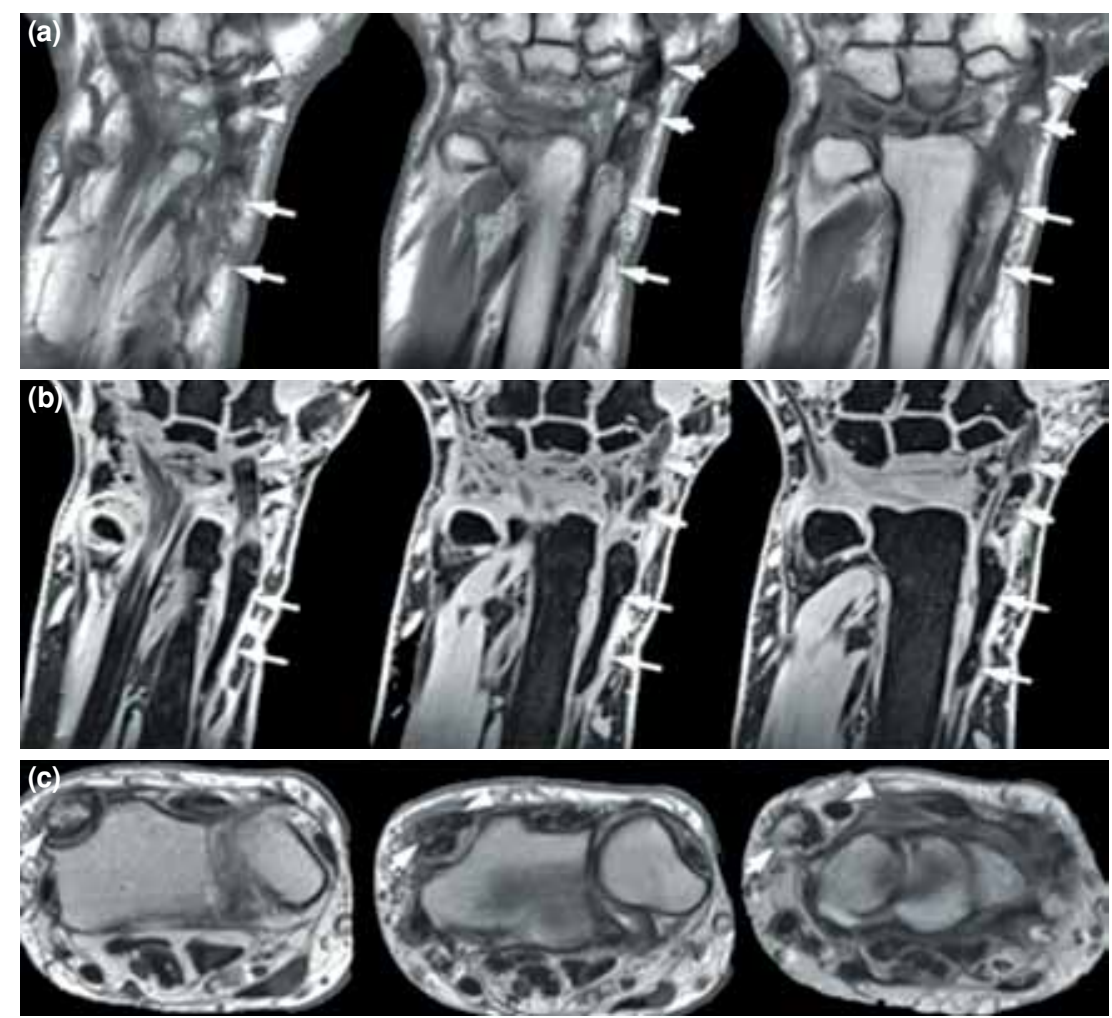

Figure 2. Coronal $\mathrm{T}_{1}$-weighted (a), gradient-echo sequences (b), and axial $\mathrm{T}_{2}$-weighted (c) consecutive magnetic resonance images show ossification of extensor carpi radialis tendon group proximal to the Lister tubercle (long arrows). Magnetic resonance images also demonstrate calcification and ossification continuing separately within the extensor carpi radialis longus (short arrows) and extensor carpi radialis brevis (arrowheads) at distal level of Lister tubercle. 
for the deposition of calcium. ${ }^{[3,10,11]}$ The later was proposed by Uhthoff et al., ${ }^{[12]}$ as they did not find any evidence for an active or healed degenerative process after the clinical and morphological investigations on 46 surgically treated cases to elucidate the pathogenesis of calcifying tendinitis. The affected tendon was transformed into fibrocartilage with a predilection for calcification. The formative phase of calcification was followed by a resorptive phase in which the deposits were surrounded by phagocytic cells. A concomitant proliferation of vascular channels was also found.

An acute, painful synovitis can accompany the release of calcium salts into the intrasynovial space in joints or tenosynovial sheaths that mimics an infectious process. Hypercalcemia is neither necessary nor sufficient to produce ectopic calcifications. Conventional radiographs may reveal a large deposit of fluffy calcium, or they may be completely normal. Posteroanterior, lateral and oblique radiographs may be necessary to demonstrate soft tissue calcium deposit. ${ }^{[3]}$ Similarly, laboratory values were found as normal and radiographic analysis showed the calcific deposits in the soft tissues at the distal and lateral aspect of radius in this case.

Cohen reported the first case of acute calcific tendinitis over flexor carpi ulnaris insertion to pisiform bone in 1924. ${ }^{[13]}$ Calcified tendinitis of flexor carpi ulnaris was reported as the most frequent entity among calcific tendinitis in the hand since then. ${ }^{[10,11]}$ In this study, we have presented a SREPL related calcific ECRTG. The diagnosis of calcificossific ECRL was confirmed by conventional radiography and MRI. Other factors that cause SREPL were reported as systemic or local steroid injections, wrist fracture, tenosynovitis, synovitis, RA, gouty tenosynovitis, and repetitive hand and wrist motions (such as milking cow, goalkeeping, or downhill skiing). ${ }^{[1-8]}$ In our case, we could not find any correlation with the causes of calcific tendinitis that were mentioned above.

The surgical techniques recommended in case of EPL ruptures are end-to-end repair, intercalated tendon graft, and tendon transfers (EIP and extensor carpi radialis longus). ${ }^{[14]}$ Since the proximal end of EPL was absent, we were not able to perform an endto-end tendon repair or intercalated tendon graft; instead, we used EIP for the repair of ruptured EPL.

In conclusion, surgeons must keep in mind that calcific ECRTG can be a causative factor for attritional
SREPL and can be successfully treated with transfer of the EIP tendon.

\section{Declaration of conflicting interests}

The authors declared no conflicts of interest with respect to the authorship and/or publication of this article.

\section{Funding}

The authors received no financial support for the research and/or authorship of this article.

\section{REFERENCES}

1. Cigna E, Özkan Ö, Mardini S, Chiang PT, Yang CH, Chen HC. Late spontaneous rupture of the extensor pollicis longus tendon after corticosteroid injection for flexor tenosynovitis. Eur Rev Med Pharmacol Sci 2013;17:845-8.

2. Brooker B, Harris PC, Donnan LT, Graham HK. Rupture of the extensor pollicis longus tendon following dorsal entry flexible nailing of radial shaft fractures in children. J Child Orthop 2014;8:353-7.

3. Wolfe SW. Tenosynovitis. In: Gren DP, Hotchkiss RN, Pederson WC, Wolfe SW, editors. Green's Operative Hand Surgery. Philadelphia: Churchill Livingstone; 2005. p. 2137-58.

4. Ozalp T, Ozdemir O, Coşkunol E, Erkan S, Calli IH. Extensor indicis proprius transfers for extensor pollicis longus ruptures secondary to rheumatoid arthritis. [Article in Turkish] Acta Orthop Traumatol Turc 2007;41:48-52.

5. Hung JY, Wang SJ, Wu SS. Spontaneous rupture of extensor pollicis longus tendon with tophaceous gout infiltration. Arch Orthop Trauma Surg 2005;125:281-4.

6. Taş S, Balta S, Benlier E. Spontaneous Rupture of the Extensor Pollicis Longus Tendon due to Unusual Etiology. Balkan Med J 2014;31:105-6.

7. Perugia D, Ciurluini M, Ferretti A. Spontaneous rupture of the extensor pollicis longus tendon in a young goalkeeper: a case report. Scand J Med Sci Sports 2009;19:257-9.

8. Fujita N, Doita M, Yoshikawa M, Fujioka H, Sha N, Yoshiya S. Spontaneous rupture of the extensor pollicis longus tendon in a professional skier. Knee Surg Sports Traumatol Arthrosc 2005;13:489-91.

9. Atik OŞ. Are all case reports worth publishing? Eklem Hastalik Cerrahisi 2016;27:61.

10. Moyer RA, Bush DC, Harrington TM. Acute calcific tendinitis of the hand and wrist: a report of 12 cases and a review of the literature. J Rheumatol 1989;16:198-202.

11. Nikci V, Doumas C. Calcium deposits in the hand and wrist. J Am Acad Orthop Surg 2015;23:87-94.

12. Uhthoff HK, Sarkar K, Maynard JA. Calcifying tendinitis: a new concept of its pathogenesis. Clin Orthop Relat Res 1976;118:164-8.

13. Cohen I. Calcareous Deposit at the Insertion of Flexor Carpi Ulnaris Tendon Following Trauma. Am J Surg 1924;38:172-3.

14. Andrew PF, Terrono AL, Nalebuff EA, Millender LH. Rheumatoid arthritis and other connective tissue diseases. In: Gren DP, Hotchkiss RN, Pederson WC, Wolfe SW, editors. Green's Operative Hand Surgery. Philadelphia: Churchill Livingstone; 2005. p. 2149-71. 